\title{
Compassion Education for Prosocial Behavior and Well-Being Among College Students
}

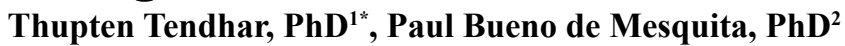 \\ I*Inner Peace Healthy Minds Program, URI Center for Nonviolence \& Peace Studies, 74 Lower College Road-MSSC202, The \\ University of Rhode Island, Kingston, RI, 02881, USA. \\ ${ }^{2}$ Professor, Department of Psychology, College of Health Sciences, Director, Center for Nonviolence \& Peace Studies, The \\ University of Rhode Island, 74 Lower College Road-MSSC202, Kingston, RI 02881, USA.
}

\section{Article Details \\ Article Type: Research Article \\ Received date: $15^{\text {th }}$ February, 2020 \\ Accepted date: $14^{\text {th }}$ March, 2020 \\ Published date: $18^{\text {th }}$ March, 2020}

*Corresponding Author: Thupten Tendhar, Inner Peace Healthy Minds Program, URI Center for Nonviolence \& Peace Studies, 74 Lower College Road - MSSC202, The University of Rhode Island, Kingston, RI 02881, USA. E-mail: thuptendar@uri.edu

Citation: Tendhar, T., Bueno de Mesquita, P. (2020). Compassion Education for Prosocial Behavior and Well-Being Among College Students. J Ment Health Soc Behav 2(1):115. https://doi.org/10.33790/jmhsb1100115

Copyright: (C2020, This is an open-access article distributed under the terms of the Creative Commons Attribution License 4.0, which permits unrestricted use, distribution, and reproduction in any medium, provided the original author and source are credited.

\begin{abstract}
Recent studies indicate that many young adults, especially US college students, experience high levels of stress, depression, anxiety, cyberbullying, and sexual violence. Many institutions of higher education rely on policies that often are reportedly biased towards materialistic pursuits, science and mathematics curriculums, and standardized testing which may promote students' extrinsic motivation and individualistic behaviors. This review examines the potential benefits of compassion education to enhance the prosocial attitudes, mental health, and well-being among undergraduate college students. The two overarching goals of this paper are first, to highlight the current mental health challenges facing undergraduate college students and their causes, and second, to propose possible solutions to address these issues. Data from empirical studies on compassion are reviewed to examine the effectiveness of compassion education and training approaches in establishing a safer, healthier, happier, and more inclusive educational learning environment leading to enhanced prosocial behaviors and positive mental health.
\end{abstract}

\section{Introduction}

Education is an active process of enriching the human mind and heart to transform perceptions, attitudes and behaviors toward being constructive and proactive for the betterment of the community. It should be well-rounded and purposeful in overcoming physical, mental, emotional, spiritual, and environmental challenges [1]. Hence, it is an optimal force to fight poverty, crime, injustice, oppression, and suffering [2]. Yet, many students in higher educational institutions are suffering from negative emotions and anti-social behaviors that may foster more crime, feelings of injustice, and pain during their matriculation and beyond. This review seeks to examine the potential benefits of compassion education to enhance prosocial attitudes and well-being among undergraduate college students.

In order to understand the need for compassion education, we need to evaluate current adverse situations of undergraduate college students and their root causes, including education reform policies. It is important to review education reform policies as they are directly related to student learning experiences. This paper has two overarching goals: first, to highlight the current difficulties of undergraduate college students and their causes, and second, to presentpossible solutions to these issues. Toward these ends this review will be divided into three sections. In the first section, several areas of students' stress, such as depression, anxiety, cyberbullying, and sexual assault will be addressed to examine the menace of negative emotions and antisocial behaviors will be reviewed. In the second section, several education reform policies will be reviewed to examine their preference towards materialistic pursuits, in science and mathematics curricula, and standardized testing which may promote students' extrinsic motivation and individualistic behaviors. Finally, an argument for why compassion education would be a remedy for negative emotions, antisocial behaviors, and the vulnerable sense of well-being of self and others will be provided.

\section{Maladaptive Development \\ Negative Emotions}

Negative emotions such as stress, depression, and anxiety, are tormenting the lives of many youth on college campuses $[3,4]$. According to the American Institute of Stress, stress is generally defined as, "a condition or feeling experienced when a person perceives that demands exceed the personal and social resources the individual is able to mobilize." The stress that college students experience in higher education is also growing nationally and internationally [5]. A study with 508 undergraduate college students aged between 18 and 24 indicated that at least one in four participants reported symptoms of stress, depression, or anxiety [4].

Unfortunately, intense levels of stress can weaken resilience factors, such as forgiveness [6] and hope [7] among undergraduate college students [8]. Hope was found to have a robust relationship with college students' retention and their academic performance [9]. Other studies have shown that stress could affect students' emotional as well as physical health profoundly, and that experiencing persistent stress can weaken one's immune system [10,11]. Moreover, excessive stress can cause psychological and physical impairment to students [12]. Depression is deemed the most common emotional reaction to one's persistent pain [13].

A study sampled from 26 colleges and universities in the US showed that $17 \%$ of the student participants have depression symptoms [14]. Another study reported that $25 \%$ of college students shared disclosing depression symptoms on Facebook [15]. Suicidal thoughts are often associated with depression [16], and suicide is the second leading cause of death among US college students, costing lives of around 1,100 
students a year [17].

The prevalence of anxiety among the undergraduate population is also high. Approximately 15.6 percent of 1,181 undergraduate participants reported having depressive or anxiety disorders [3]. A study with 439 students found that social anxiety has a negative impact on students' academic adjustments [18]. Moreover, social anxiety disorder is an adolescent-onset disorder that may consistently and substantially increase the risk for successive depression [19]. Thus, it is very important to address college students' issues of stress, depression, and anxiety by uplifting their positive energy and improving their physical and mental well-beings.

\section{Antisocial Behavior}

A significant number of college students experience adverse effects of antisocial behaviors such as cyberbullying and sexual assaults. Cyberbullying can be defined as an intentional aggressive action carried out by an individual or a group who use electronic information and communication to repeatedly victimize others [20, 21]. A study on cyberbullying among college students indicated that $8.6 \%$ of the participants had cyberbullied someone else, $21.9 \%$ were cyberbullied, and $38 \%$ knew someone who was cyberbullied [22]. Both cyberbullying victims and offenders are found to have lower levels of self-esteem than their peers, suggesting that low self-esteem is both a potential trigger of as well as outcome from cyberbullying [23].

Sexual assault is an act of interpersonal violence that inflicts significant risk of negative physical and psychological outcomes [24]. A large body of research shows endemic rates of sexual victimization among college students [25], and an increasing number of sexual violence cases in US colleges [26]. Findings from the study on the risk factors for (PTSD) and depression in female survivors of rape supported pervious literature on the negative mental health consequences on the survivors including posttraumatic stress and depression [27].

\section{Educational Policy and Practical Impact}

Ever since "A Nation At Risk" was published by the US Department of Education in 1983, there have been multiple attempts to change the American public schooling system and its outcomes [28]. Unfortunately, many of these reform policies are fueled by the fear of losing "American supremacy" and intention for economic profits only. Indeed, the previous three presidents Reagan, George Bush, and Bill Clinton) talked about the improvement of the economy as the main purpose of education, as if economy is the key and only factor in one's social and personal fulfillment [29]. Accordingly, the primary goal of reforming education was set for outcomes that were geared toward career and materialistic pursuits. These goals and outcomes, however, undermine and even ignore prosocial values, such as compassion, loving-kindness, and nonviolence.

The Goals 2000: Educate America Act was signed into law by the then US president on March 31, 1994. According to the policy, the national education goals were to increase the high school graduation rate to at least 90 percent, and for US students to come in first for science and mathematics achievement by the year 2000 [30]. In fact, it was only in 2015 when the nation's high school graduation reached the record high of 83 percent [31]. It has been argued that rather than working on any specific substantive reform, Goals 2000 was focused on shifting the authority of educational policymaking [32]. The "School Reform 2000" removed power from teachers, students, parents, and the American society to entertain the whims of a few politicians and technocrats [33].

The No Child Left Behind Act of 2001 (NCLB) which was signed into law on January 8, 2002 was another federal government's attempt to guarantee high quality education for every child in America [34] By requiring states to improve and monitor students' performance, it seeks to prepare students with skills and abilities for problem solving in the twenty first century [35]. It also tried to increase funding for the school districts with underprivileged students [36]. However, various mandates of the NCLB, such as creating and issuing school report cards accessible to the public based on standardized test results created tension, fear, threat, and stigma related to test failure among teachers and school leaders. The NCLB left little room for innovation, critical thinking, and creativity - skills that are needed for the twenty first century as schools struggle to meet their adequate yearly progress report [37]. Many schools had to cut back on subjects that were not measured or tested [38]. Thus, NCLB had an adverse impact on schools because curriculum was narrowed down and teachers were teaching to the tests [39].

The Race to the Top (RTTT) policy was authorized and incepted in 2009 under the American Recovery and Reinvestment Act [40]. The policy could be described as the federal government's aggressive attempt to push education policy although the government made serious efforts to coordinate the policy with events that were taking place in the states [41]. RTTT encourages states to develop and implement the following four main components: "Adopting rigorous college- and career-ready standards and assessments," "recruiting, evaluating, and retaining highly effective teachers and principals," "building data systems that measure student success and inform teaching and learning," and "turning around low-performing schools" [42].

Under this policy, rather than giving grants to schools on a needbasis, the federal government invites states to compete for RTTT grants. One of the six requirements for the RTTT grant applications is to have Great Teachers and Leaders, and schools with Great Teachers are awarded the greatest points. The RTTT focuses on the effectiveness of teachers as measured by a combination of students' growth indicators and observation-based assessments [40]. This creates an equity issue because students from minority and low-income communities are attending schools with less qualified teachers and limited resources compared to students in wealthier communities [43, 44, 45]. Although RTTT was praised for reaching an important milestone - "widespread move to college- and careerready standards - within a short period of time" [42], the policy has been criticized by some education scholars for perpetuating the inequality divide of individual development and human capital [46].

Overall, the federal policies such as Goals 2000, No Child Left Behind and Race to the Top are biased towards science and mathematics studies primarily for economic reasons [47]. Today, more and more nations view higher education as their major engine for financial development [48]. Education today is highly commercialized, and college students are burdened with increasing amount of debt due to a loan-based aid system and escalated tuition fees $[49,50]$. Many students are judged "applaudable" or "nonapplaudable" based on their standardized test scores, and their enrollment into higher educational institutes are determined by scores designed by test companies. College graduates who are unable to fulfill the expectation of becoming the fuel to run their nation's economies may run the risk of being regarded as nobodies by society.

According to American education philosopher John Dewey (1916) education should be ethical and humane. Nevertheless, education curricula in the US today are being designed and taught primarily to boost the nation's Gross Domestic Product (GDP) and to satisfy the needs of labor markets. This forces student to seek extrinsic motivations for their studies and to shy away from "non-pragmatic" values such as peace, harmony, compassion, and positive contributions to humankind. If we continue to drive that train in the same direction, instead of reaching our intended destination, we will harm millions of students by reducing the quality of their education [38].

\section{Educational Policy and Behavior}

Education policies of Goals 2000, No Child Left Behind 
and Race to the Top certainly encourage students to compete with each other for individual profits rather than cooperate with one another for the larger social good. It promotes a false notion of independent self among students who are in fact part of the human society, and dependent on each other's sympathy for well-being [51]. Guided by such policies, students may identify schoolmates as their competitors rather than supportive friends. Today, empathetic concern, a motivator for prosocial behaviors [52], is declining sharply among American college students followed by perspective taking [53].

These mindsets can have adverse effect on the students' attitude toward prosocial behaviors and in turn social connections, which are critical for one's happiness [54]. The direction toward antisocial and individualistic goals may lead students further and further away from being prosocial.

Empathy helps people to connect with others at an emotional level and foster interpersonal behaviors [55]. Having emotional closeness toward others is very important since it safeguards oneself from the negative effects of stress and suffering [56]. Because students' negative emotions and anti-social behaviors are not favorable in a healthy society, it is of utmost importance and urgency for us to revisit today's education policies and realign polices and academic curriculums to prosocial behaviors for the common good. Specifically, interpersonal skills, such as empathy and compassion that are associated with increased helping and prosocial behavior [57, 58] should be taught and fostered from K-12 and through college.

\section{Compassion as an Antidote \\ Compassion Education}

Compassion can be defined as a sensitivity to the suffering of self and others with a deep commitment to try to relieve it [59]. Compassion has also been defined as a feeling that arises when witnessing the sufferings of others and that motivates subsequent desires to help [60,61]. Education is far more than knowing how to read books or use numbers [38], or training youths merely for jobs. Education is an active process of enriching the human mind and heart, and it should be constructive and purposeful for the betterment of humanity. Compassion should not be discarded from education because it is a basic human value rooted in the recognition of a desire to alleviate suffering and help increase prosocial behaviors [62] Therefore, compassion should be adorned in education policies, and incorporated into curriculums.

\section{Compassion and Positive Emotions}

A study on the impact of compassionate thinking among undergraduate students found that students who practiced compassionate thinking reported significantly lower frequencies of negative emotions compared to students in the control group [65]. This finding is similar to previous studies that found that compassion acts as a protective agent that counters negativity and supports social connection [66]. A pilot study with chronic pain patients found that the Compassion Cultivation Training (CCT) was effective in reducing significant levels of anger and pain among participating female patients [67]. Compassion training has also been found to increase positive mood and decrease negative mood [58].

A study conducted with 571 undergraduate nursing students indicated a positive correlation between emotional intelligence and self-compassion [68]. Another study reported that the CCT intervention group reported a decrease in emotional suppression and worry, and an increase in mindfulness and happiness comparing to the waitlist group [69]. In another study, compassion meditation and loving kindness meditations were found to be highly promising methods to reduce stress and anxiety and improve positive affect [70].

\section{Compassion and Prosocial Behavior}

Even short-term compassion training has been found to have significant positive impacts on prosocial behavior [58]. Prosocial behavior includes a broad range of actions, such as comforting, helping, cooperating, and sharing with intention to benefit one or more persons [71]. Compassion was found to reduce one's engagement in punishment and avoidance in escalation of aggression [72]. For instance, a compassion study using Cognitive Based Compassion Training (CBCT) method reported that its teenager participants tried to behave more compassionately in times of anger and stress [73]. Developing prosocial behavior is important because many experimental studies have found prosocial activities to increase human happiness [74].

\section{Compassion and Social Connections}

Compassion interventions have been proven to be efficient in improving social connections [75]. Deep individual and social connections arise when there is respect and caring for self and others [76]. There is a strong scientific evidence that shows the short-term and long-term effects of social relationship on one's health. Social connection is also closely related to morality, mental and physical health [77], greater happiness [78], and longevity [74].

By increasing emotional regulation and cognitive ability, social connectedness may help people to find calmness under stressful and adverse circumstances, and to help them endure difficulties [75]. A study conducted with 485 college students attending a Midwestern public university shows that students who reported higher emotional closeness to others reported lower perceived stress [79]. The study also indicated that one's emotional relationship and stress level make significant difference in student's perceived happiness. Those students who feel profoundly connected do not need weapons or hurt themselves or others to feel powerful, and their connection with people help them grow compassion and passion for life [76].

\section{Compassion and Well-being}

The development of compassion is very important for adaptive social interactions and the maintenance of physical and mental health especially during times of distress in one's life [64, 80]. Studies on self-compassion have reported a positive association between selfcompassion and psychological well-being [81]. Another study has found that viewing and treating oneself with compassion is a strong way to increase intrapersonal as well as interpersonal wellbeing [82]. A study on CCT program found that compassion was effective in reducing significant amount of worry and increasing mindfulness and happiness [69].

\section{Conclusion}

Recent studies indicated that many US college students experience high levels of stress, depression, and anxiety [4]. There are also significant increases in sexual violence [25] and cyberbullying [22] on campuses. These negative emotions and behaviors may cause harm to the physical and mental well-being of both perpetrators and the survivors. These negative emotions and actions could be prevented or at least minimized if one understands and practices compassion. While empathy may help people to make emotional connections with others and thus to develop interpersonal behavior [55], and morality helps people to understand acceptable or unacceptable customs of behaviors in a society [83], compassion education has far more benefits. Compassion would not only enhance interpersonal connections and positive behaviors, but also increase the sense of hopeful [73], psychological well-being [81], physical well-being [84], mindfulness, and happiness [69] to the givers themselves. Therefore, compassion education would be a holistic and wholesome approach to establishing a safer, healthier, happier, and more inclusive campus environment for young adult college students facing the challenges and stressors of today's fast paced modern lifestyle. As the benefits of compassion education at all levels of schooling become clearer, scholars and researchers will need to focus their attention on determining the most effective pedagogies for delivering a compassion-oriented curriculum. 


\section{Acknowledgements}

The authors wish to express their gratitude for the research assistance of Emma Vincent and for the support of the Inner Peace-Healthy Minds Program with the Center for Nonviolence \& Peace Studies and the Department of Psychology, College of Health Sciences at the University of Rhode Island.

Conflicts of Interest: The authors declare no conflicts of interest.

\section{References}

1. Orr, D. W. (2004). Earth in mind: On education, environment, and the human prospect. Washington, D.C: Island Press.

2. Hodgkinson, H. (1991). Reform versus reality. Phi Delta Kappan, 73(1), 8-16.

3. Eisenberg, D., Gollust, S. E., Golberstein, E., \& Hefner, J. L. (2007). Prevalence and correlates of depression, anxiety, and suicidality among university students. American Journal of Orthopsychiatry, 77(4), 534-542.

4. Mahmoud, J. S. R., Staten, R. T., Hall, L. A., \& Lennie, T. A. (2012). The relationship among young adult college students' depression, anxiety, stress, demographics, life satisfaction, and coping styles. Issues in Mental Health Nursing, 33(3), 149-156.

5. Robotham, D. (2008). Stress among higher education students: Towards a research agenda. Higher Education, 56(6), 735-746.

6. Worthington, E. L., \& Scherer, M. (2004). Forgiveness is an emotion-focused coping strategy that can reduce health risks and promote health resilience: Theory, review, and hypotheses. Psychology \& Health, 19(3), 385-405.

7. Lopez, S.J., Snyder, C.R, \& Pedrotti, J.T. (2003). Hope: many definitions, many measures. In Lopez, S.J. \& Snyder, C.R. (Eds.), Positive Psychological Assessment: A Handbook of Models and Measures. (pp. 91-107) Washington, DC: American Psychological Association.

8. Oman, D., Shapiro, S. L., Thoresen, C. E., Plante, T. G., \& Flinders, T. (2008). Meditation lowers stress and supports forgiveness among college students: A randomized controlled trial. Journal of American College Health, 56(5), 569-578.

9. Gallagher, M.W., Marques, S.C. \& Lopez, S.J. (2017). Hope and the Academic Trajectory of College Students. Journal of Happiness Studies, 18(2), 341-352.

10. Geronimus, A. T., Hicken, M. T., Pearson, J. A., Seashols, S. J., Brown, K. L., \& Cruz, T. D. (2010). Do US black women experience stress-related accelerated biological aging? Human Nature, 21(1), 19-38.

11. Henslin, J. M., Possamai, A. M., Possamai-Inesedy, A. L., Marjoribanks, T., \& Elder, K. (2015). Sociology: A down to earth approach. Boston, MA: Pearson.

12. Murphy, M.C., \& Archer, J. (1996). Stressors on the college campus: A comparison of 19851993. Journal of College Student Development, 37(1), 20-28.

13. Dennis, T., \& Charles E. A. (2009). Psychological Syndromes. In Dubin, A., Pilitsis, J., Argoff, C. E., \&McCleane, G. (Eds.), Pain Management Secrets (Third Edition), p.211. Philadelphia, PA: Mosby Elsevier.

14. Hunt, J., \& Eisenberg, D. (2010). Mental health problems and help-seeking behavior among college students. Journal of Adolescent Health, 46(1), 3-10.

15. Moreno, M. A., Jelenchick, L. A., Egan, K. G., Cox, E., Young, H., Gannon, K. E., \& Becker, T. (2011). Feeling bad on Facebook: depression disclosures by college students on a social networking site. Depression and Anxiety, 28(6), 447-455.
16. Hirsch, J. K., Webb, J. R., \&Jeglic, E. L. (2011). Forgiveness, depression, and suicidal behavior among a diverse sample of college students. Journal of clinical psychology, 67(9), 896-906.

17. Wilcox, H. C., Arria, A. M., Caldeira, K. M., Vincent, K. B., Pinchevsky, G. M., \& O'Grady, K. E. (2010). Prevalence and predictors of persistent suicide ideation, plans, and attempts during college. Journal of Affective Disorders, 127(1), 287-294.

18. Arjanggi, R., \&Kusumaningsih, L. P. S. (2016). The Correlation between Social Anxiety and Academic Adjustment among Freshmen. Procedia-Social and Behavioral Sciences, 219, 104107.

19. Beesdo, K., Bittner, A., Pine, D. S., Stein, M. B., Höfler, M., Lieb, R., \&Wittchen, H. U. (2007). Incidence of social anxiety disorder and the consistent risk for secondary depression in the first three decades of life. Archives of General Psychiatry, 64(8), 903-912.

20. Belsey, B. (2004). Always on, always aware, 15-33.

21. Smith, P. K., Mahdavi, J., Carvalho, M., Fisher, S., Russell, S., \&Tippett, N. (2008). Cyberbullying: Its nature and impact in secondary school pupils. Journal of Child Psychology and Psychiatry, 49(4), 376-385.

22. MacDonald, C. D., \& Roberts-Pittman, B. (2010). Cyberbullying among college students: Prevalence and demographic differences. Procedia-Social and Behavioral Sciences, 9, 20032009.

23. Patchin, J. W., \& Hinduja, S. (2010). Cyberbullying and selfesteem. Journal of school Health, 80(12), 614-621.

24. Rothbaum, A. (2017). Sexual assault in a highly traumatized inner-city population: prevalence, associated sequelae, and psychophysiological phenotypes. (Electronic Thesis or Dissertation).

25. Edwards, K. M., Sylaska, K. M., Barry, J. E., Moynihan, M. M., Banyard, V. L., Cohn, E. S., \& Ward, S. K. (2015). Physical dating violence, sexual violence, and unwanted pursuit victimization: A comparison of incidence rates among sexual-minority and heterosexual college students. Journal of Interpersonal Violence, 30(4), 580-600.

26. Mantel, B. (2014). Campus Sexual Assault: Do colleges handle allegations fairly? CQ Researcher, 24(39), 913-936.

27. Mbalo, N., Zhang, M., \&Ntuli, S. (2017). Risk factors for PTSD and depression in female survivors of rape. Psychological Trauma: Theory, Research, Practice, and Policy.

28. Heilig, J. V., Cole, H., \& Aguilar, A. (2010). From Dewey to No Child Left Behind: The evolution and devolution of public arts education. Arts Education Policy Review, 111(4), 136-145.

29. Brell, D. 2001. Teaching as a moral enterprise. Encounter: Education for Meaning and Social Justice, 14(2) 23-29.

30. Earley, P. M. (1994). Goals 2000: Educate America Act: Implications for Teacher Educators. Washington, DC: AACTE Publications.

31. Brown, E. \& Matos, A. (2016). Nation's high school graduation rate reaches new record high. The Washington Post.

32. Heise, M. (1994). Goals 2000: Educate America Act: The Federalization and Legislation of Educational Policy. Fordham L. Rev., 63, 345.

33. Willis, G. "School Reform 2000 a Sordid Power Game." Providence Journal. September 12, 1999. p.A-13.

34. U.S. Department of Education. Program Description, Race to the Top.

35. Watters, A.P. (2015). Testing: Room for Creativity. International Journal of Innovation, Creativity and Change. 2(2), 83-96. 
36. Zoll, S. M., \&Rosenquest, B. (2011). Sustainable Practices in Mentoring: Tools to Support Child Outcomes and a Mentoring Protocol in Early Language and Literacy. NHSA Dialog, 14(4), 213-228.

37. Schoen, L., \& Fusarelli, L. D. (2008). Innovation, NCLB, and the fear factor: The challenge of leading 21 st-century schools in an era of accountability. Educational Policy, 22(1), 181-203.

38. Ravitch, D. (2013). Reign of error: The hoax of the privatization movement and the danger to America's public schools. New York City, NY: Vintage.

39. Jones, G. M., Jones, B. D., \& Hargrove, T. (2003). The unintended consequences of highstakes testing. Lenham, MD: Rowman \& Littlefield Publishers Inc.

40. Mangiante, E. M. S. (2011). Teachers matter: Measures of teacher effectiveness in low income minority schools. Educational Assessment, Evaluation and Accountability, 23(1), 41-63.

41. Viteritti, J. P. (2011). The Federal Role in School Reform: Obama's Race to the Top. Notre Dame L. Rev., 87, 2087.

42. Miller, T. D., \& Hanna, R. (2014). Four Years Later, Are Race to the Top States on Track?. Center for American Progress, 1-12.

43. Lankford, H., Loeb, S., \& Wyckoff, J. (2002). Teacher sorting and the plight of urban schools: A descriptive analysis. Educational Evaluation and Policy Analysis, 24(1), 37-62.

44. Darling-Hammond, L. (2004). From "separate but equal" to "no child left behind": The collision of new standards and old inequalities. In Meier, D. \& Wood, G. (Eds.), Many children left behind. (pp. 3-32). Boston, MA: Beacon Press.

45. Kozol, J. (2005). The shame of the nation: The restoration of apartheid schooling in America. New York City, NY: Crown Publishers.

46. Onosko, J. (2011). Race to the Top leaves children and future citizens behind: The devastating effects of centralization, standardization, and high stakes accountability. Democracy and Education, 19(2), 1

47. Smyth, T. S. (2008). Who Is No Child Left Behind Leaving Behind? The Clearing House: A Journal of Educational Strategies, Issues and Ideas, 81(3), 133-137.

48. Altbach, P. G., Reisberg, L., \&Rumbley, L. E. (2009). Trends in global higher education: Tracking an academic revolution. UNESCO 2009 World Conference on Higher Education: Executive Summary. Paris: Center for International Higher Education.

49. Worthy, S. L., Jonkman, J., \& Blinn-Pike, L. (2010). Sensationseeking, risk-taking, and problematic financial behaviors of college students. Journal of Family and Economic Issues, 31(2), 161-170.

50. Hillman, N. W. (2014). College on credit: A multilevel analysis of student loan default. The Review of Higher Education, 37(2), 169-195.

51. Kitayama, S. \& Markus H.R. (2000). The pursuit of happiness and the realization of sympathy: Cultural patterns of self, social relations, and well-being. In Diener, E. \& Suh. E. (Eds.) Subjective well-being across cultures. (pp. 113-161). Cambridge, MA: MIT Press.

52. Bartal, I. B. A., Decety, J., \& Mason, P. (2011). Empathy and pro-social behavior in rats. Science, 334(6061), 1427-1430.

53. Konrath, S. H., O'Brien, E. H., \&Hsing, C. (2011). Changes in dispositional empathy in American college students over time: A meta-analysis. Personality and Social Psychology Review, 15(2), 180-198.
54. Cacioppo, J. T., Hawkley, L. C., Kalil, A., Hughes, M. E., Waite, L., \& Thisted, R. A. (2008). Happiness and the invisible threads of social connection. The Science of Subjective Well-being, 195-219.

55. Shdo, S. M., Ranasinghe, K. G., Gola, K. A., Mielke, C. J., Sukhanov, P. V., Miller, B. L., \& Rankin, K. P. (2017). Deconstructing empathy: Neuroanatomical dissociations between affect sharing and prosocial motivation using a patient lesion model. Neuropsychologia.

56. Sai Wong, K., \& Hing Cheuk, W. (2005). Job-related stress and social support in kindergarten principals: the case of Macau. International Journal of Educational Management, 19(3), 183196.

57. Batson, C. D., Eklund, J. H., Chermok, V. L., Hoyt, J. L., \& Ortiz, B. G. (2007). An additional antecedent of empathic concern: valuing the welfare of the person in need. Journal of Personality and Social Psychology, 93(1), 65.

58. Leiberg, S., Klimecki, O., \& Singer, T. (2011). Short-term compassion training increases prosocial behavior in a newly developed prosocial game. PloS ONE, 6(3), e17798.

59. Dalai Lama, XIV (2001). The compassionate life. Boston, MA: Wisdom Publication.

60. Batson, C. D., O'Quin, K., Fultz, J., Vanderplas, M., \& Isen, A. M. (1983). Influence of self-reported distress and empathy on egoistic versus altruistic motivation to help. Journal of Personality and Social Psychology, 45(3), 706.

61. Goetz, J. L., Keltner, D., Simon-Thomas, E. (2010). Compassion: An evolutionary analysis and empirical review. Psychological Bulletin, 136(3), 351-374.

62. Dalai Lama, XIV. (1995). The power of compassion. New York, NY: Harper Collins.

63. Jazaieri, H., Jinpa, G. T., McGonigal, K., Rosenberg, E. L., Finkelstein, J., Simon-Thomas, E., ... \& Goldin, P. R. (2013). Enhancing compassion: a randomized controlled trial of a compassion cultivation training program. Journal of Happiness Studies, 14(4), 1113-1126.

64. Klimecki, O. M., Leiberg, S., Lamm, C., \& Singer, T. (2013). Functional neural plasticity and associated changes in positive affect after compassion training. Cerebral Cortex, 23 (7), 15521561.

65. Arimitsu, K., \& Hofmann, S. G. (2015). Effects of compassionate thinking on negative emotions. Cognition and Emotion, 1-8.

66. Pommier, E. A. (2010). The compassion scale. (Doctoral dissertation), The University of Texas at Austin.

67. Chapin, H. L., Darnall, B. D., Seppala, E. M., Doty, J. R., Hah, J. M., \& Mackey, S. C. (2014). Pilot study of a compassion meditation intervention in chronic pain. Journal of Compassionate Health Care, 1(1), 4.

68. Şenyuva, E., Kaya, H., Işik, B., \&Bodur, G. (2014). Relationship between self-compassion and emotional intelligence in nursing students. International Journal of Nursing Practice, 20(6), 588596.

69. Jazaieri, H., McGonigal, K., Jinpa, T., Doty, J. R., Gross, J. J., \& Goldin, P. R. (2014). A randomized controlled trial of compassion cultivation training: Effects on mindfulness, affect, and emotion regulation. Motivation and Emotion, 38(1), 23-35.

70. Hofmann, S. G., Grossman, P., \& Hinton, D. E. (2011). Loving-kindness and compassion meditation: Potential for psychological interventions. Clinical psychology review, 31(7), 1126-1132. 
71. 71. Batson, C. D., \& Powell, A. A. (2003). Altruism and prosocial behavior. In Million, T., Lerner, M.J., \& Weiner, I.B. (Eds.) Handbook of Psychology. (pp. 463-484). Hoboken, NJ: John Wiley \& Sons, Inc.

72. Condon, P., \&DeSteno, D. (2011). Compassion for one reduces punishment for another. Journal of Experimental Social Psychology, 47(3), 698-701.

73. Reddy, S. D., Negi, L. T., Dodson-Lavelle, B., Ozawa-de Silva, B., Pace, T. W., Cole, S. P., \& Craighead, L. W. (2013). Cognitive-Based Compassion Training: a promising prevention strategy for at-risk adolescents. Journal of Child and Family Studies, 22(2), 219-230.

74. Brown, S. L., Nesse, R. M., Vinokur, A. D., \& Smith, D. M. (2003). Providing social support may be more beneficial than receiving it results from a prospective study of mortality. Psychological Science, 14(4), 320-327.

75. Seppala, E., Rossomando, T., \& Doty, J. R. (2013). Social connection and compassion: Important predictors of health and well-being. Social Research, 80(2), 411-430.

76. Kessler, R. (2000). The soul of education: Helping students find connection, compassion, and character at school. Alexandria, VA: ASCD Publications.

77. Umberson, D., \& Montez, J. K. (2010). Social relationships and health a flashpoint for health policy. Journal of Health and Social Behavior, 51(1 suppl), S54-S66.
78. Mogilner, C. (2010). The pursuit of happiness time, money, and social connection. Psychological Science, 21(9), 1348-1354.

79. King, K. A., Vidourek, R. A., Merianous, A., \& Singh, M. (2014). A study of stress, social support, and perceived happiness among college students. Journal of Happiness and Wellbeing, 2(2), 132-44.

80. Klimecki, O. M., Leiberg, S., Ricard, M., \& Singer, T. (2014). Differential pattern of functional brain plasticity after compassion and empathy training. Social Cognitive and Affective Neuroscience, 9(6), 873-879.

81. Neff, K. D., Kirkpatrick, K. L., \& Rude, S. S. (2007). Selfcompassion and adaptive psychological functioning. Journal of Research in Personality, 41(1), 139-154.

82. Neff, K. D., \& Dahm, K. A. (2014). Self-compassion: What it is, what it does, and how it relates to mindfulness. Mindfulness and self-regulation. New York: Springer.

83. Garcia-Zamor, J. (2012). A Theoretical Guideline to define Transparency and Accountability in Public Organizations. Global Advanced Research Journal of Social Science, 1(7), 142-151.

84. Hall, C. W., Row, K. A., Wuensch, K. L., \& Godley, K. R. (2013). The role of self-compassion in physical and psychological wellbeing. The Journal of Psychology, 147(4), 311-323. 